\begin{tabular}{|c|c|c|c|}
\hline \multicolumn{3}{|c|}{ MANUSCRIT ACCEPTAT } & \\
\hline \multicolumn{3}{|c|}{$\begin{array}{l}\text { Marble Pieces in the Romanesque Portal of } \\
\text { Glory of the Santiago de Compostela } \\
\text { Cathedral. New Data through a Multi- } \\
\text { Analytical Approach }\end{array}$} & 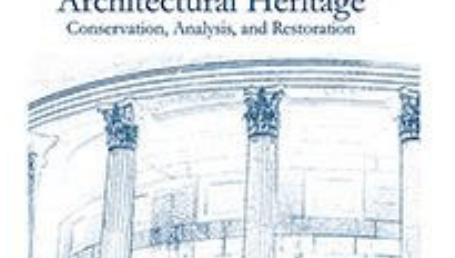 \\
\hline \multicolumn{3}{|c|}{$\begin{array}{l}\text { Pilar Lapuente Mercadal, Marie-Claire Savin, Silvia } \\
\text { González Soutelo, Anna Gutiérrez Garcia-M., Rémy } \\
\text { Chapouli, Ana Laborde Marqueze, Pedro Pablo Pérez } \\
\text { García. }\end{array}$} & 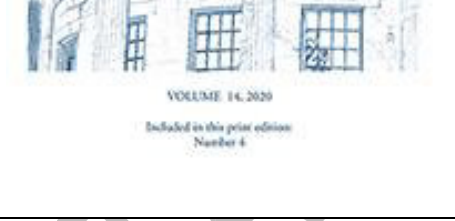 \\
\hline Revista & \multicolumn{3}{|c|}{ International Journal of Architectural Heritage } \\
\hline DOI & \multicolumn{3}{|c|}{ https://doi.org/10.1080/15583058.2019.1602683 } \\
\hline $\begin{array}{l}\text { Disponible } \\
\text { en línia }\end{array}$ & $19 / 04 / 2019$ & Data de publicació & $19 / 04 / 2019$ \\
\hline \multicolumn{4}{|c|}{$\begin{array}{l}\text { Per citar aquest document: } \\
\text { Pilar Lapuente Mercadal, Marie-Claire Savin, Silvia González Soutelo, Anna Gutiérrez Garcia-M., } \\
\text { Rémy Chapoulie, Ana Laborde Marqueze \& Pedro Pablo Pérez García (2019) Marble Pieces in } \\
\text { the Romanesque Portal of Glory of the Santiago de Compostela Cathedral. New Data through a } \\
\text { Multi-Analytical Approach, International Journal of Architectural Heritage, DOI: } \\
\text { 10.1080/15583058.2019.1602683 }\end{array}$} \\
\hline
\end{tabular}




\title{
Marble pieces in the Romanesque Portal of Glory of the Santiago de Compostela Cathedral. New data through a multi-analytical approach
}

\author{
Pilar Lapuente Mercadal ${ }^{* a, b}$, Marie-Claire Savin ${ }^{c}$, Silvia González Soutelo ${ }^{d}$, Anna Gutiérrez \\ Garcia-M. ${ }^{b}$, Rémy Chapoulie ${ }^{c}$, Ana Laborde Marqueze ${ }^{e}$, Pedro Pablo Pérez García ${ }^{e, f}$ \\ aPetrology and Geochemistry, Earth Sciences Dept., Zaragoza University, C/ Pedro Cerbuna, 12, \\ 50009 Zaragoza, Spain \\ bInstitut Català d'Arqueologia Clàssica (ICAC), Plaça d'en Rovellat s/n, 43003 Tarragona, Spain \\ cInstitut de Recherche sur les ArchéoMATériaux (IRAMAT), Centre de Recherche en Physique \\ Appliquée à l'Archéologie (CRP2A), UMR 5060 CNRS, Université Bordeaux Montaigne, France \\ 'Grupo de Estudos de Arqueoloxía, Antigüidade e Territorio (GEAAT), Universidade de Vigo and \\ Universidad Autónoma de Madrid/MIAS, Spain \\ eInstituto del Patrimonio Cultural de España, C/ Pintor el Greco, 4, 28040 Madrid, Spain \\ fDACITEC SL, Spain
}

*Corresponding author: plapuent@unizar.es ORCiD: 0000-0002-8321-2396

\begin{abstract}
Probably the most important Romanesque artwork in Spain, the Portal of Glory of Santiago de Compostela is essentially made in granite, the most abundant stone in the NW of Iberia, with the only exception of five marble pieces. Different hypothesis on the origin of these marbles have previously been proposed based on visual assessment or by directly assuming a local source. To shed light on their quarry provenance, a multi-analytical study was performed combining polarized-light optical microscopy, cathodoluminescence microscopy, XRPD, SEM-EDS and stable $\mathrm{C}$ and $\mathrm{O}$ isotopes. The comparison of the results with the available databases reveals the use of marbles from the Estremoz Anticline (Portugal) in the three exquisitely carved columns strategically placed in the central arcade, whereas the other two pieces are local marbles, illustrating a more complex consumption of this noble material than that initially expected.
\end{abstract}

KEYWORDS: provenance; marble; Romanesque Galicia; Estremoz Anticline 


\section{Introduction}

Recognized as one of the most valuable Romanesque jewels in Europe, the Portal of Glory is the western narthex of the Santiago de Compostela Cathedral in Galicia, Spain (Figure 1). It consists of a set of three semi-circular arches, the central being twice as large as the sides, with a total of 168 sculptured figures (Figure 2). They are so expressive that they seem to be an animated picture composing a theological message focused on the salvation of humanity, a representation of the Celestial Jerusalem described by St. John. This sculptural set, of approximate $17 \mathrm{~m}$ long by $9.5 \mathrm{~m}$ high, originally painted with the most vivid pigments and luxurious materials, was mostly carved in local granite with the exception of five marble pieces, which are the object of this study.

\subsection{Brief architectural evolution of the Santiago de Compostela Cathedral}

During the reign of Alfonso II (791-842), the remains of St James the Greater were said to have been discovered in the North-West of Spain. In order to protect and venerate the Apostle relics, subsequent kings enhanced the construction of monumental churches in the place known as Santiago de Compostela (A Coruña, Spain) which would become a multitudinous pilgrimage destination in Western Europe. The first sanctuary was erected under Alfonso II the Chaste and according to the Acta instaurationis ecclesie beati iacobi ${ }^{1}$, it consisted in as a modest church made of "stones and clay" (ex petra et luto opera parvo) (Díaz Bustamante and López Pereira 1988, 253-4). This structure was soon replaced by a new bigger building ordered by the king Alfonso III (866-910). This second sanctuary was consecrated in 899 and, contrary to the first one, it was said to have been built using ornamental materials like

\footnotetext{
${ }^{1}$ The validity of the only copy of this Visigothic text, a $17^{\text {th }}$ century version, is object of controversy among scholars.
} 
marbles $^{2}$ and jaspers (del Hoyo 1697). In fact, the aforementioned Acta instaurationis indicates that Alfonso III had marbles transported to Santiago de Compostela from southern conquered territories, mainly from the unknown Ebeca/Aucca-Caucae (Sánchez Albornoz 1979) identified by some researchers as the ancient Roman town of Coria, in the Cáceres province (Díaz Bustamante and López Pereira 1988; López Pereira 1993). This act would have been a way for this Christian monarch to demonstrate his power against the Moors, as those territories were under Muslim rule from the Umayyad conquest of Hispania, and it would also provide noble material for the reconstruction of the second basilica. However, this second temple was only in use for one century until its destruction in 997 by the Muslim siege conducted by the general Almanzor and rebuilt later in a third and definitive sanctuary. The building process of the Romanesque Cathedral was complex and slow, beginning in 1075 under the impetus of Bishop Diego Peláez and the king Alfonso VI and was finally consecrated by the king Alfonso IX of León, in 1211.

Remodelling the western façade was the last stage of the building process which was directed by Master Mateo who also led the works of the Portal of Glory, monumental structure completed in $1188^{3}$. During the following centuries, new Gothic and Baroque structures were added to the Romanesque Cathedral changing its morphology over time and giving it its present appearance, in which the Portal of Glory was protected in the interior of the western

\footnotetext{
${ }^{2}$ During the archaeological excavations of the Cathedral in the 20th century, some small pieces of marbles were discovered among the ruins of the Alfonso III basilica, most of them parts of shafts and Corinthian capitals dated from the 4th century AD (Suárez Otero 2003, 57). Several authors have discussed about the origin of marbles employed in the Alfonso III church (Sánchez Albornoz 1979; Díaz Bustamante and López Pereira 1988; and López Pereira 1993, among others).

${ }^{3}$ Despite whether Master Mateo's work was the restitution of a previous western portico or not has been object of debate for a long time, today there seems to be agreement among researchers that one portal referred to in the Codex Calixtinus existed before Master Mateo's work (Watson 2000). In any case, two unquestionable dates are documented, the contract between king Fernando II and Mateo in 1168 and, twenty years later, the completion of the work written on the lintels.
} 
Baroque façade. Structural failures, the presence of continuous damp and the effects of natural weathering in adverse climate conditions have caused serious decay problems all over this millennial building (Silva et al. 1994). Consequently, during recent decades, it has undergone a thorough restoration and preventive plan, the Santiago Cathedral Program ${ }^{4}$.

\subsection{The Portal of Glory. The artwork of Master Mateo}

The study of the emblematic western narthex of the Santiago Cathedral has been the focus of many researchers, since it is one of the best documented Romanesque architectural and sculptural sets (Vidal Rodríguez 1926; Gaillard 1958; Ward 1978; Moralejo 1985; Castiñeiras 1999; Yzquierdo Perrín 2010; Nicolai and Rheidt 2015). Recognized as the height of the Romanesque art in transition to Gothic aesthetics, the Pórtico de la Gloria was a unique and universal project which concentrated master builders, masons and highly qualified painters to design an avant-garde space carrying out the most innovative trends and techniques of that moment. The statuary of this triple portal offers the spectacle of the resources of an art that is varied in its expression, details, workmanship and polychromy. The recovery of its material and immaterial values, as a whole, has been addressed based on the consideration that this illustrative work of the history of art is an indissoluble part of the western façade of the temple. The Portal not only has a powerful symbolic and liturgical value as a place of worship and pilgrimage, but is also one of the most outstanding international tourist destinations.

\footnotetext{
${ }^{4}$ Bringing together the central and regional administrations (Ministry of Culture and Xunta de Galicia) and two private foundations (Barrié de la Maza and Santiago Cathedral), this Program is an example of institutional collaboration for the conservation of Cultural Heritage. From the beginning, it has been focused on research attracting many national and international specialists from different disciplines, who have contributed their experience to deepen the knowledge of various aspects such as the different construction stages, transformations of the space and use, significance, iconographic program, materials used for carving, decorative techniques and the adaptation of its aesthetics throughout the centuries.
} 
For centuries the Portal of Glory not only served as the main entrance through the Cathedral but also became the major platform and principal vehicle for the communication of religious messages and political outlines (Raitt 2014). The tripartite structure shows Christ in Majesty at its centre, surrounded by the representation of apostles, prophets, and evangelists. Both semi-arch sides display scenes from the Old Testament on the left and from the Final Judgment on the right. The whole scene is framed by the central archivolt representing the 24 Elders of the Apocalypse, each one holding a musical instrument. Three columns of high quality marble, in white and grey bands are located in the central arch structure (Figure 3). The southern and the northern are twisted, finely decorated columns, whereas the central one (trumeau) bisects the central doorway and represents the linage of Christ through the tree of Jesse. A fourth decorated column in homogeneous grey marble, with evidence of slight stone decay, is placed in the extreme northern arcade with no respective counterpart on the other side, breaking the symmetry. A fifth element carved in white marble is the head of one apostle, traditionally identified as Saint Andrew. This has been ignored for years due to its location at half height in the southern arcade, and thus out of the direct sight from the ground floor (Figure 2).

One of the main interests in the preventive studies prior to the restoration works was to recognize the nature of the stones and their quarry provenance. As the majority of the artwork is in granite, the presence of those five unique marble pieces is surprising. Equally outstanding is the high quality of the sculptural work achieved in granite, a material extremely difficult to carve. At least, three varieties of granite were differentiated (De la Torre Martín-Romo 2011; Morabito 2011): a medium to coarse grained variety with a high content of potassium feldspar used in the walls masonry for the smooth ashlars of the façade and counter-façade; a leucocratic fine grained granite, for certain columns and sculptural or decorative works and a granite with fine to medium grain size and yellowish brown colour, 
used mainly in sculptural work. Being all local raw materials, two different main areas of granite bodies close to Santiago are their potential sources of supply: the area of ConxoVidán with medium to coarse grained granite, and the area of Pedroso-Monte FontecovaVrins where medium to fine grained granites have been quarried out.

During the intervention plan in the recent restoration works, the existence of three polychrome phases was confirmed, all of them with linen oil, which must have changed the appearance of the Portal over the centuries (Cortázar García de Salazar and Sánchez Ledesma 2017). Only few vestiges of the first medieval decoration are preserved but thanks to the exhaustive analytic study carried out on each sculpture ${ }^{5}$, its component paints and the meticulous technique executed were identified, especially that related to the flesh tone. This first polychrome, applied using the most expensive pigments (lapis lazuli, vermilion, red lacquer, green lacquer, lead white and black bone, among others) and luxurious materials (pure gold and silver leaves), was evidently carried out at a time close to the construction of the Portal of Glory. This original Romanesque polychromy is of such an outstanding technique and richness of colour, that even in some cases the presence of clear decorative motifs of tunics and mantles has been detected. The second polychrome discovered probably dates from the $16^{\text {th }}$ century, when the western access was modified and significant repair works were undertaken in the temple, whereas the third was certainly done by Crispín de Evelino in 1651, as documented in the archives of the Cathedral.

\section{Research aim}

If polychromy and granite are now well documented, the study of the five marble elements deserves no less attention. They also show traces of the first medieval polychromy dated at

\footnotetext{
${ }^{5}$ Using stereoscopic microscopy contrasted in the laboratory with stratigraphic analysis, gas chromatography, infrared spectroscopy, Raman spectroscopy, diffraction and X-ray fluorescence, among others.
} 
the beginning of $13^{\text {th }}$ century, but their importance stems from their uniqueness in the granite ensemble. Thus, different hypotheses of provenance had been put forward but until now, no archaeometric analysis has yet been carried out. Most scholars assume the logical use of local raw material from Galician marble quarries (López-Ferreiro 1899; Ward 1978; Portela Silva 1985; García Iglesias 2009, 2011) and for others, they could be reused spolia materials from elements of the pre-Romanesque basilica, but there is no mention of quarry sources. This latter idea dates back to the 1860's (Villa-Amil 1866) and according to the documentary sources, as explained above in paragraph 1.1, these marbles could be part of the loot achieved by the king Alfonso III. The aim of this paper is to analyze these marble pieces with a twofold objective: firstly to check the application of our multi-method analytical database recently created on local marble outcrops and secondly, to determine their provenance in order to clarify the mentioned hypotheses and common beliefs.

\section{Multi-analytical approach. Methodology}

The restoration of the Portico was an exceptional occasion to sample these valuable pieces of marble. The installation of scaffolding facilitated the close visual inspection to select the proper areas in each stone. On the one hand, the heterogeneity of colors and patterns in the marble directly affects the selection of the sample to be representative and on the other, the extraction of a small chip must not alter the aesthetics or the integrity of the piece. After macroscopic examination, differences in the state of conservation were registered and millimetric samples, discretely chiselled off, were taken and conveniently documented.

Several analytical techniques were applied following a sequential approach (Lapuente, 2014) to identify the marble provenance of the five artifacts. They combine Polarized-light optical microscopy (OM), Cathodoluminescence microscopy (CL), X-ray power diffraction (XRPD), Scanning electron microscope equipped with energy dispersive spectrometer (SEM-EDS) and 
Isotope ratio mass spectrometry (IRMS) to determine $\mathrm{C}$ and $\mathrm{O}$ isotopes. Results were compared to those obtained, using the same methodology, in a wide collection of quarry marbles, being local (Gutiérrez Garcia-M. et al. 2016), supra-regional (Lapuente 1995; Lapuente and Turi 1995; Lapuente, Turi, and Blanc 2000; Lapuente et al. 2002, 2014, 2018; Origlia et al. 2011) and classical marbles (Gorgoni et al. 2002; Capedri et al. 2004; Attanasio, Brilli, and Ogle 2006; Attanasio, Bruno, and Yavuz 2009; Attanasio et al. 2015, 2017; Lapuente et al. 2012; Antonelli and Lazzarini 2015; Brilli et al. 2015, 2018).

Thin sections were made from all the five samples, and before their powdering, weathered surfaces were previously abraded to avoid possible contamination. OM was used to examine the mineralogy, fabric, texture, grain boundary shape (GBS) and to determine the maximum grain size (MGS). Combined with other analytical results, these parameters have a particular diagnostic significance for discriminating the provenance of many ancient marbles, since they are strictly related to their respective metamorphic history, as many references pointed out.

The presence of accessory minerals was checked by XRPD, under CL and using complementary analyses by SEM-EDS (model JEOL JMS 6460 LV, Oxford Industries INCA $\mathrm{x}$-sight, calibrated using natural standards). XRPD was carried out with an automatic Philips PW 1130/00 diffractometer (CuKa radiation at $40 \mathrm{kV}, 20 \mathrm{~mA}$; data recorded in the $3^{\circ}-70^{\circ}$ $2 \Phi$ range, $1 \% \mathrm{~min}, 2 \mathrm{~s} / \mathrm{step})$. CL was observed with CL8200 Mk5-1 cold equipment coupled to a NIKON Eclipse 50iPOL OM. The electron energy was $15-20 \mathrm{kV}$ and the beam current was operated at 250-300mA. The luminescent colours, their intensity and distribution in each sample were recorded with an automatic digital NIKON COOLPIX5400 camera. The CL images taken were automatically controlled (29 $\mathrm{mm}$ focal length, $\mathrm{f} / 4.6$ aperture, $1 \mathrm{~s}$ exposure, ISO-200) to obtain comparative images. It is well known that the CL characteristics of carbonates are related to their chemical impurities which can provide diagnostic CL 
microfacies that help to identify some varieties of marble (Lapuente and Royo 2016). The optical CL images were checked with those available from several classical quarrying areas (Barbin et al. 1989, 1992; Lapuente et al. 2012), including those from the French Pyrenees (Royo et al. 2015; 2018) and from ancient Iberian quarries (Lapuente, Turi, and Blanc 2000, Lapuente et al. 2014; Lapuente and Blanc 2002; Àlvarez et al. 2009; Gutiérrez Garcia-M. et al. 2016).

Oxygen and Carbon isotopes were determined by isotope ratio mass spectrometry (IRMS) with Finnigan MAT 252 equipment. A Finnigan MAT Kiel II automatic preparation device was previously used for phosphoric acid digestion at $72^{\circ} \mathrm{C}$ and $\mathrm{CO} 2$ purification. The results were expressed in terms of usual delta notation $\left(\delta^{13} \mathrm{C}\right.$ and $\left.\delta^{18} \mathrm{O}\right)$ in parts per thousand relative to the international reference standard PDB. Analytical precision was better than $0.1 \%$ for both isotopic determinations. The isotopic signatures of the marble pieces were compared with those of the main classical and Iberian marbles reported elsewhere. In addition, an updated isotopic diagram of the most relevant quarry district in the NW of Iberia is provided based on unpublished data recently achieved in the framework of the $\mathrm{PhD}$ Thesis in progress of one author (M-C S.), (Figure 4A).

\section{Results and discussion}

The results of the mineralogical-petrographic examination, the main CL characteristics and the $\delta^{18} \mathrm{O}$ and $\delta^{13} \mathrm{C}(\mathrm{PDB})$ values are displayed in Table 1. They are all fine grained calcitic marbles, with an average grain size less than $0.9 \mathrm{~mm}$ in length and mostly a MGS $<2 \mathrm{~mm}$, in the limit of fine and medium size, or slightly larger in one sample, all with anisotropic fabric and mainly heteroblastic but show different microstructure-textures depending on the thinsection orientation. 


\subsection{The three central columns}

The macroscopic observation of the marble columns from the central arch revealed a variety of white-grey veined marbles, very hard and compact exhibiting an exceptional state of conservation (Figure 3). They all show a moderate translucency in the white parts which display light cream tones. The southern twisted column (SAN1) is irregularly banded in white and grey, with the grey bands of several centimeters in width. The mullion (SAN2) is also white but crossed by spotted and irregular grey-to-bluish bands and veins with fairly strong contrasts, as can be fully appreciated in the handprint polished by the hands of thousands of pilgrims. In detail, it also shows sheath micro-folds in darker grey and rare reddish streaks. The northern twisted column is almost white with scarce thin grey veins. In fresh cut, the analysed sample (SAN3) is white with light cream pinkish patches.

The macroscopic irregularities of these three non-uniform white or white and grey banded marbles are also represented, on a microscopic scale, by a variety of textural aspects related to the presence of microcrystalline aggregates formed by accessory minerals (Table 1). Dolomite, mono and polycrystalline quartz with subrounded morphologies, in addition to phlogopite, iron oxide impurities and sporadic pyrite are mainly scattered or grouped in lenses, non-luminescent under CL (SAN1). All show anisotropic fabric with non-penetrative foliation, either by preferential orientation of elongate calcite, by the disposition of the microcrystalline lenticular or banded aggregates, or by a certain crystallographic preferred orientation. All these aspects and others such as the deformation of carbonate twins and undulating extinction manifest signs of dynamic recrystallization in accordance to a complex structural tectono-metamorphic evolution with various phases of deformation.

The macro and micro features match well with those present in the fine grained marbles from the Ossa Morena Zone of the Iberian Massif, in particular from the Cambrian-Ordovician 
metacarbonate sequence of the Estremoz Anticline (Alto Alentejo, Portugal) and Almadén de la Plata (Seville) districts (Lapuente et al. 2014). Though certain classical fine-medium grained marbles exhibit similar petrographic characteristics, with anisotropic fabric, deformed shape grain foliation and MGS like those from Mount Pentelicon in Athens, the presence of phlogopite as an accessory makes this Greek origin incompatible with our samples (Capedri and Venturelli 2004). Furthermore, their different CL-patterns help to discriminate them from this classical marble, as will be discussed below.

Their isotopic values are quite uniform, ranging from -5.30 to $-6.60 \%$ o $\left(\delta^{18} \mathrm{O}\right)$ and from 1.36 to $1.98 \%\left(\delta^{13} \mathrm{C}\right)$ reinforcing a possible common origin (Table 1). Plotted on the general isotopic diagram for the white and white/grey fine-medium grained marbles, including classical marbles and supra-regional marble sources (Figure 4B), they are all within the same isotopic cluster of the Lusitanian marbles from the Estremoz Anticline, outside any other isotopic field of Hispanic marbles, clearly apart from the updated local O Incio (Lugo) isotopic field, but overlapping the cluster of Docimium and Pentelicon marbles.

With regard to $\mathrm{CL}$, the three columns show a similar behaviour with faint to medium intensity. These CL-microfacies give them a character that certainly confirms the Lusitanian origin. Indeed, the heterogeneous distribution and the variable intensity (from faint to medium or to moderately strong), typical of these Portuguese marbles, helps to discriminate them not only from the Almadén de la Plata marble which exhibits homogeneous CL-patterns in strong to very strong intensities (Lapuente and Blanc 2002; Lapuente et al. 2014), but also from other classical marbles such as Pentelicon and Docimium. Marbles from these Greek and Turkish districts exhibit peculiar patchy CL-patterns combining areas of very different intensities unrelated to any specific crystal which give them a very distinctive characteristic (Barbin et al. 1989, 1992; Lapuente and Royo 2016). 
In summary, all the parameters and features of the three central columns described, point to an undoubtedly Lusitanian origin in the Estremoz Anticline marble district.

\subsection{The apostle's head traditionally identified as Saint Andrew}

Sample SAN4 corresponds to a white fine grained marble with a lamination of light grey parallel bands and fine grey veins, which became more visible after cleaning (Figure 5). It shows traces of paint, the remains of the first original polychromy. The grade of compactness is less than those exhibited by the other four studied samples, offering a somewhat sugary look, saccharoidal, with no translucent power. Compared with the above mentioned white and white/grey banded marbles, despite being quite similar in most of the mineralogicalpetrographic and CL features (Table 1), the apostle's head shows two parameters which help to discriminate it clearly from the others. One is its finer grain size (MGS $<0.8 \mathrm{~mm}$ ), in accordance with the size of certain Galician marbles, and the second, the $\mathrm{C}$ and $\mathrm{O}$ isotopic data, with a very low $\delta^{18} \mathrm{O}$ value (-10.4\%o). Indeed, this isotopic signature serves to rule out the classical marble districts and the supra-regional ones as possible source origins, but on the contrary, matches well with the isotopic data of the local O Incio marbles. As Figure 4B shows, its $\delta^{13} \mathrm{C}$ and $\delta^{18} \mathrm{O}$ values falls within the isotopic cluster from this Galician district, updated with additional data of quarry marbles in Figure 4A. Furthermore, the mineralogicalpetrographic and CL approach mostly agrees with published data dealing with these local marbles (Gutiérrez Garcia-M. et al. 2016). In particular, the heterogeneous CL-microfacies, fabric, texture, MGS, and even the accessory minerals, are in common with the white lithotype 1 defined from $\mathrm{O}$ Incio marbles.

\subsection{The northern grey column}

Contrary to the three previously discussed white or white /grey banded columns, the northernmost column (sample SAN5) is visually distinctive by its uniform grey colour 
(Figure 3). Despite being quite hard and compact, the sculptured relief is not as well preserved as the other three columns. However the dimensions of all four are quite the same, ranging from 1.725 to $1.75 \mathrm{~m}$ long and with a diameter of $0.24-0.25 \mathrm{~m}$. This fine grained marble exhibits an anisotropic fabric with deformed shape grain foliation, and slightly heteroblastic texture, whose petrographic and CL features are analogous to those shown in certain local and supra-regional marbles, but quite different from other Iberian marbles. In particular, the grey marbles from the Hispanic districts of Macael, Almadén de la Plata, Alconera and Viana do Alentejo must be ruled out due to their distinctive medium to strong CL intensities (Lapuente, Turi, and Blanc 2000, Lapuente et al. 2014). However, some marbles of the Estremoz Anticline and local marbles from $\mathrm{O}$ Incio could be comparable in petrography and CL response. In fact, macroscopically, the colour of this column looks not only similar to the grey bands of lithotype 2 defined in the O Incio quarry samples (Gutiérrez Garcia-M. et al. 2016) but also to certain columns used in the Romanesque church of San Pedro Fiz de Hospital, in the O Incio village.

Nevertheless, the isotopic data plotted in the diagram for grey marbles (Figure 6) help to confirm this local provenance. The distinctive low $\delta^{18} \mathrm{O}$ value $(-11.16 \%$ of this fourth decorated column falls on the limit of the updated isotopic cluster of O Incio (Figure 4A), rejecting all the most famous grey classical marbles (known as bigio antico), and other supraregional districts like those mentioned above of Lusitanian marbles.

\section{Conclusions}

A simultaneous presence of local and supra-regional marbles has been evidenced through this multi-analytical approach applied to the five unique pieces of the Romanesque Portal of Glory. Comparing their physical and compositional parameters with the available database, 
three samples match perfectly well with specific marbles collected in quarries of the southern part of the Estremoz Anticline in the Alentejo region of Portugal. This result is an important breakthrough because until now it was commonly accepted that these columns were made of local Galician marble.

Furthermore, this source attribution has additional significant implications. On the one hand, this is the first time that this Portuguese marble has been analytically detected in the Galician medieval architecture, where the use of marble for sculpture and architecture is not unknown, yet quite rare in comparison with granite and traditionally considered to be of Galician origin. On the other hand, but also in this same sense, the attested presence of this Lusitanian marble in a place as far from its area of production as Santiago de Compostela at a time when it was no longer in trading networks, leads us to consider the possibility that these columns were reshaped from previous marble elements, reused and decorated when the Portal of Glory was built.

Indeed, it is well known that Estremoz Anticline marble was exploited and widely used in ancient times, especially by the Romans from Early Imperial times until the Late Roman period, as evidenced by the studies carried out in archaeological pieces not only from the capital of Lusitania, Augusta Emerita (Lapuente, Turi, and Blanc 2000; Lapuente et al. 2014), but also from areas relatively distant from the quarries such as Caesar Augusta in the NE of Hispania (Lapuente et al. 2016; Nogales, Lapuente, and Rodà 2017) and even in the North of Africa (Antonelli et al. 2015). In accordance with this distribution, Estremoz Anticline marble also reached the northern regions of Roman Spain, as proven by a few, rare examples of sarcophagi (González Soutelo, Gutiérrez Garcia-M., and Royo 2018; Vidal, Gutiérrez Garcia-M., and García-Entero 2016). However, in Medieval times this material was no longer the object of long-distance transport in trade networks, and in particular not with a Christian reign established in the NW of the Iberian Peninsula, since the quarries were at that time 
under Muslim control. Therefore, it seems extremely unlikely that the marble used for these columns was of primary use, while the hypothesis of being recycled material from previous Roman objects becomes stronger.

At this point, two questions arise in the light of the unquestionable fact of being Estremoz Anticline marbles. First, are there any arguments to explain a possible re-use from a local Roman monument? Or should the presence of Estremoz Anticline marbles be related to a longer distance transport of these spolia? In response to these questions, it can be said that there is no evidence for the first option as, at the moment, the scarce Roman and Late Roman marble architectural pieces documented and archaeometrically analysed in this NW sector of Hispania are of local provenance (see, for example, González Soutelo et al. 2016; González Soutelo and Gutiérrez Garcia-M. forthcoming); Gutiérrez Garcia-M., Royo, and González Soutelo 2018).

By contrast, the transport of large marble objects from central and southern Iberia to the northern regions as part of military raids booty or to be used for prestige elements, is documented in this period (González Soutelo, Gutiérrez Garcia-M., and Royo 2018). Although it is not possible to confirm with absolute certainty whether the marbles were actually moved in the Christian raid from the ancient Roman city of Coria, or from some other places, it does reinforce the idea, in agreement to the written sources, that these spolia could have been part of the loot brought to Santiago by order of Alfonso III. Moreover, the fact that the Estremoz Anticline marbles were widely used in the territories of the ancient Lusitania, not only in sculpture but also in architectural decorative elements of great size, adds weight to attributing these columns as part of the materials mentioned in the Acta instaurationis and used in the pre-Romanesque basilica. 
Concerning the other two marbles pieces (the fourth column and the apostle's head), the scenery is completely different. The comparison with the multi-method analytical database recently created on local marble outcrops makes it possible to assign both of them to marbles from Galician quarries. The homogeneous grey colour and the results of its archaeometric analysis, which point to the $\mathrm{O}$ Incio marble district, clearly set the fourth column apart from the other three. However, the question of whether it was carved ex novo for the Portal of Glory or, alternatively, carved from a pre-existing local marble piece is much harder to elucidate. Although we cannot rule out this second hypothesis, the fact that the Romanesque church of San Pedro Fiz de Hospital, in the same village of O Incio, was entirely built of marble proves that materials from this district were in use during the last decades of the $12^{\text {th }}$ century. Consequently, it is reasonable to believe that Master Matthews might have ordered it specifically for the Portal. The apparent stone decay of this fourth column, which has been put forward by some scholars as a sign of being recycled from the old façade (Moralejo 1991,16), could also be due, in fact, to the slightly lower quality of this local marble in comparison to that of the Estremoz Anticline.

In any case, given the high degree of thought put into the creation of the Portal of Glory, for which the best artisans and materials were made available, it seems likely that the presence of marble, though rarely represented in the total of the stone pieces, plays a special role. Indeed, the use of such a noble and highly appreciated material must be emphasized as a strongly symbolic act. The strategic location of the three marble columns in the central arcade, added to their exquisite carving, point to a special significance of its use, probably due to the fact that they were spolia elements. As for the fourth local column, regardless of whether it was made ex novo or was spolia, it is difficult to understand why it was included in the extreme northern arcade with no respective counterpart on the other side, and thus breaking up the symmetry. Considering the importance of the symbolic message used by Master Mateo, 
perhaps even with the presence of polychromy, it could be an indication towards the importance of the original grey colour of the marble.

Concerning the enigmatic marble head, it has been possible to confirm without doubt that it was carved from local $\mathrm{O}$ Incio marble. If the discovery of it being made of marble is already remarkable, its identification as a Galician source for such a beautiful work of art is even more outstanding. The exceptionality of this portrait goes beyond the fact that is the only one in marble on the whole Portal of Glory, as it is also a rare example of the use of the best variety of O Incio marbles (lithotype 1, defined in Gutiérrez Garcia-M. et al. 2016) for a freestanding sculpture. In fact, so far, the use of this white local marble has been attested only in decorative reliefs and architectural elements such as capitals, even from the first examples of its use in late Roman times (González Soutelo et al. 2016).

Further questions arise from this latter element, for which there are no easy answers. In particular, and regardless of whether it was reused or not, why is it the only marble portrait in a set almost entirely made of granite? There seems to be an apparent contradiction between the use of such material (white, homogeneous, fine-grained marble which is perfect for achieving high-quality detail in sculptural work) and its presence almost out of sight from the ground floor. Again, the answer must lie in the symbolism of Master Mateo's work. Additionally, the remains of pigments belonging to the first medieval polychromy confirm its authenticity, ensuring that it was not added to the granite artwork at any later time.

Finally, the advantages of a multidisciplinary approach such us the one followed in this study must be emphasized. This is an ideal example of the mutual benefit obtained from the collaborative work to improve our knowledge of this exceptional artwork, where the documentary sources are cross-checked by the analytical studies of marble provenance. Furthermore, the identification of a non-local marble origin inevitably obliges us to 
reconsider previous assumptions and draw attention to the need of performing archaeometric analysis on other medieval marble elements, since it is evident that the panorama in which Romanesque art was being created in this far corner of the Iberian Peninsula is in fact much more complex than previously thought.

\section{Acknowledgements and Funding}

This contribution has been developed within the confluence of two research programs, the "Santiago Cathedral Project" and the "Marmora Galicia" project. The first, sponsored by several international and Spanish Institutions: Foundations of Barrié, Santiago Cathedral, Andrew W. Mellon, Harvard's Real Colegio Complutense; the Spanish Cultural Heritage Institute and the Xunta of Galicia, committed to the conservation of the Cathedral. The second, concerns an interdisciplinary research program with a double objective, creating a database of the marble lithotypes from the main quarries in the NW of Hispania, and their complementary application on the most relevant archeological and historical pieces made in marble found in the same territory. This work was supported by the Spanish MICINN and European FEDER founds (HAR2011-25011 and HAR2015-65319-P), in collaboration with the LabEx Sciencies Archéologiques de Bordeaux (ANR-10-LABX-52) through the "Graver dans le marbre" (ROMAE) project (2016-2018); and by the E20_17R Research Group (GMG) of Zaragoza University. The authors are grateful for the sampling facilities to the Servizo de Patrimonio de la Xunta de Galicia, Fundación Catedral de Santiago and Museo Catedralicio; and Dr Brilli from the Instituto di Geologia Ambientale e Geoingegneria, CNR, in Rome, for his contribution (ISRM). 


\section{References}

Àlvarez, A., Domènech, A., Lapuente, P., Pitarch A., and Royo, H. 2009. Marbles and stones of Hispania. Exhibition Catalogue. ICAC. Tarragona. 143p.

Antonelli, F., Lapuente Mercadal, P., Dessandier, D., and Kamel, S. 2015. Petrographic Characterization and Provenance Determination of the Crystalline Marbles Used in the Roman City of Banasa (Morocco): New Data on the Import of Iberian Marble in Roman North Africa. Archaeometry, 57:405-425. doi:10.1111/arcm.12099.

Antonelli, F., and Lazzarini, L. 2015. An updated petrographic and isotopic reference database for white marbles used in antiquity. Rendiconti Lincei. 26:399-413. doi:10.1007/s12210-015-0423-4.

Attanasio, D., Bruno, M., Prochaska, W., and Yavuz, A.B. 2017. Ancient "Black" Decorative Stones and the Ephesian Origin of Sculptural bigio antico: The Ephesian origin of sculptural bigio antico. Archaeometry 59:794-814. doi:10.1111/arcm.12278.

Attanasio, D. Bruno, M. Prochaska, W., and Yavuz, A.B. 2015. A Multi-Method Database of the Black and White Marbles of Göktepe (Aphrodisias), including isotopic, EPR, trace and petrographic data. Archaeometry. 57:217-245. doi:10.1111/arcm.12076.

Attanasio, D., Bruno, M., and Yavuz, A.B. 2009. Quarries in the region of Aphrodisias: the black and white marbles of Göktepe (Muğla). J. Roman Archaeol. 22:312-348. doi:10.1017/S1047759400020729.

Attanasio, D., Brilli, M., and Ogle, N. 2006. The isotopic signature of classical marbles, Stud. Archaeol., 145, L'Erma di Bretschneider, Roma.

Barbin, V., Ramseyer, K., Decrouez D., Burns, S.J., Chamay, J., and Maier, J.L. 1992. Cathodoluminescence of white marbles: an overview, Archaeometry. 34:175-183. doi:10.1111/j.1475-4754.1992.tb00490.x.

Barbin, V., Ramseyer, K., Decrouez, D., and Herb, R. 1989. Marbres blancs: caractérisation par cathodoluminescence, Comptes Rendus Académie Sci. Paris. 308: 861-866.

Brilli M., Lapuente Mercadal, M.P., Giustini, F., and Royo Plumed, H. 2018. Petrography and mineralogy of the white marble and black stone of Göktepe (Muğla, Turkey) used in 
antiquity: New data for provenance determination. Journal of Archaeological Science: Reports 19:625-642. doi:10.1016/j.jasrep.2018.03.037.

Brilli, M., Giustini, F., Conte, A.M., Lapuente Mercadal, P., Quarta, G., Royo Plumed, H., Scardozzi, G., and Belardi, G. 2015. Petrography, geochemistry, and cathodoluminescence of ancient white marble from quarries in the southern Phrygia and northern Caria regions of Turkey: Considerations on provenance discrimination, Journal of Archaeological Science: Reports 4:124-142. doi:10.1016/j.jasrep.2015.08.036.

Burkhard, M. 1993. Calcite twins, their geometry, appearance and significance as stressstrain markers and indicators of tectonic regime: a review. Journal of Structural Geology, $15: 351-368$.

Capedri, S. Venturelli, G., and Photiades, A. 2004. Accessory minerals and $\delta^{18} \mathrm{O}$ and $\delta^{13} \mathrm{C}$ of marbles from the Mediterranean area. Journal of Cultural Heritage 5: 27-47. doi:10.1016/j.culher.2003.03.003.

De La Torre Martín-Romo, R. 2011. Aspectos técnicos y constructivos del Pórtico de la Gloria. Informe para COOBEC, dentro de la $2^{\mathrm{a}}$ fase de Restauración del Pórtico de la Gloria. 153 pp.

del Hoyo, C.J. [1697] 1950. Memorias del Arzobispado de Santiago, Porto y Cía Editores, Santiago de Compostela.

Capedri, S., and Venturelli, G. 2004. Accessory minerals as tracers in the provenancing of archaeological marbles, used in combination with isotopic and petrographic data, Archaeometry. 46:517-536. doi:10.1111/j.1475-4754.2004.00171.x.

Castiñeiras González, M.A. 1999. El Pórtico de la Gloria, San Pablo, Madrid.

Cortázar García de Salazar, M., and Sánchez Ledesma, A. 2017. Estudio de la secuencia de policromías y de la composición de los materiales empleados en las decoraciones del conjunto escultórico del Pórtico de la Gloria de la Catedral de Santiago de Compostela. Informes y Trabajos. Instituto del Patrimonio Cultural de España, 15, 114-169.

Díaz de Bustamante, J.M., and López Pereira, J.E. 1988. El Acta instaurationis ecclesie beati iacobi: texto y pretexto. In Actas del I Congreso de la Asociación Hispánica de Literatura 
Medieval, Santiago Compostela, 2 al 6 Diciembre 1985, Promociones y Publicaciones Universitarias, PPU, Barcelona, 247-262.

Gaillard, G. 1958. Le Porche de la Gloire à Saint-Jacques de Compostelle et ses origines espagnoles, Cahiers de civilisation médiévale, 1:465-473. doi:10.3406/ccmed.1958.1068.

García Iglesias, J.M. 2009. La mano del parteluz del Pórtico de la Gloria. Santiago de Compostela. De la leyenda a la Historia. BSAA Arte, 75:31-42.

García-Iglesias, J.M. 2011. Sobre la iconografía de Santiago el Mayor en su Catedral de Compostela. CCPAN, 5:47-78.

González Soutelo, S., and Gutiérrez Garcia-M, A. El proyecto Marmora Galicia: Identificación y estudio de la explotación, empleo y circulación de los mármoles en el NW peninsular desde época romana. In: V. García-Entero (Ed.), forthcoming.

González Soutelo, S., Gutiérrez Garcia-M., A., and Royo Plumed, H. 2018. El sarcófago romano de Tui (Pontevedra): un ejemplo de la presencia de material marmóreo foráneo en el noroeste de la Península Ibérica, SPAL, 27:229-246. doi:10.12795/spal.2018i27.21.

González Soutelo, S., Vidal Álvarez, S., Gutiérrez Garcia-M., A., and Royo Plumed, H. 2016. La placa de Amiadoso (Allariz, Ourense): Nuevos datos sobre el uso del mármol local en el noroeste de Hispania a partir de un estudio interdisciplinar. Espacio Tiempo y Forma. Serie I, Prehistoria y Arqueología, 99-121. doi:10.5944/etfi.9.2016.

Gorgoni, C., Lazzarini, L., Pallante, P., and Turi, B. 2002. An updated and detailed mineropetrographic and $\mathrm{C}-\mathrm{O}$ stable isotopic reference database for the main Mediterranean marbles used in antiquity. In: Asmosia 5. Interdisciplinary studies on ancient stone, ed. J.J. Herrmann Jr., N. Herz, and R. Newman, 115-131. Archetype Publications, London.

Gutiérrez Garcia-M., A., Royo Plumed, H., and González Soutelo S. 2015. New Data on Spanish marbles: the case of Gallaecia (NW Spain). In: ASMOSIA XI Interdisciplinary Studies on Ancient Stone. Proceedings of the XI ASMOSIA Conference (Split 2015), ed. D. Matetić Poljak, and K. Marasović, 401-411. Arts Academy in Split and Faculty of Civil Engineering, Architecture and Geodesy, University of Split. 
Gutiérrez Garcia-M., A., Royo Plumed, H., González Soutelo, S., Savin, M.-C., Lapuente, P., and Chapoulie, R. 2016. The marble of O Incio (Galicia, Spain): Quarries and first archaeometric characterisation of a material used since Roman times, ArchéoSciences Rev. Archéom., 40 (40):103-177. doi:10.4000/archeosciences.4783.

Lapuente, M.P. 1995. Mineralogical, petrographical and geochemical characterization of white marbles from Hispania. In The Study of Marble and other Stones Used in Antiquity, ed. Y. Maniatis, N. Herz, and Y. Basiakos, 151-160. Archetype Publications, London. doi: 10.13140/RG.2.1.1854.4168.

Lapuente Mercadal, M.P. 2014. Archaeometry on stones. Multi-method approach to investigate stone provenance. Studied cases from Roman Hispanic marmora, Archeometriai Mühely, XI.3:149-158. urn: nbn: hu-4106.

Lapuente, P., and Blanc, Ph. 2002. Marbles from Hispania scientific approach based on cathodoluminescence. In: Asmosia 5. Interdisciplinary studies on ancient stone, ed. J.J. Herrmann Jr., N. Herz, and R. Newman, 143-151. Archetype Publications, London. doi: 10.13140/RG.2.1.1434.2247.

Lapuente, P., León, P., Nogales-Basarrate, T., Royo, H., Preite-Martinez, M., and Blanc, Ph. 2012. White sculptural materials from Villa Adriana: study of provenance. In: Interdisciplinary Studies on Ancient Stone. Proceedings IX ASMOSIA Conference (Tarragona 2009), ed. A. Gutiérrez Garcia-M., P. Lapuente, and I. Rodà, Documenta, 23:364-375. Institut Català d'Arqueologia Clàssica, Tarragona.

Lapuente, P., Nogales-Basarrate, T., Royo, H., and Brilli, M. 2014. White marble sculptures from the National Museum of Roman Art (Mérida, Spain): sources of local and imported marbles, Eur. J. Mineral. 26:333-354. doi:10.1127/0935-1221/2014/0026-2369.

Lapuente, P. Nogales-Basarrate, T. Royo Plumed, H. Brilli, M., and Savin, M-C. 2018. Grey and greyish banded marbles from the Estremoz Anticline in Lusitania. In: ASMOSIA XI Interdisciplinary Studies on Ancient Stone. Proceedings of the XI ASMOSIA Conference (Split 2015), ed. D. Matetić Poljak, and K. Marasović, 391-399. Arts Academy in Split and Faculty of Civil Engineering, Architecture and Geodesy, University of Split.

Lapuente, P., Preite-Martinez, M., Turi, B., and Blanc, Ph. 2002. Characterization of dolomitic marbles from the Malaga Province (Spain). In ASMOSIA 5. Interdisciplinary 
Studies on Ancient Stone, ed. J.J. Herrmann, Jr., N. Herz, and R. Newman, 152-162. Archetype Publications, London, doi: 10.13140/RG.2.1.2744.9443.

Lapuente Mercadal, M.P., and Royo Plumed, H. 2016. Cathodoluminescence for the characterization of ancient marble. Problems and research perspective. In: Ancient Quarries and Building Sites in Asia Minor. ed. T. Ismaelli, and G. Scardozzi, 541-548. Edipuglia, Bari. doi http://dx.doi.org/10.4475/819.

Lapuente Mercadal, P., Royo Plumed, H., Brilli, M., and Cuchí, J.A. 2016. Mármoles escultóricos romanos del Patrimonio de Aragón. Nuevas aportaciones arqueométricas. In: Actas I Congreso de Arqueología y Patrimonio Aragonés, Zaragoza 24-25 Noviembre 2015, Sesión 4. Arqueometría y nuevas tecnologías, 64:539-548. doi:10.13140/RG.2.1.4215.9763.

Lapuente, P., and Turi, B. 1995. Marbles from Portugal: Petrographic and isotopic characterization. Science and Technology for Cultural Heritage, 4:33-42.

Lapuente, M.P., Turi, B., and Blanc, Ph. 2000. Marbles from Roman Hispania: stable isotope and cathodoluminescence characterization, Appl. Geochem. 15 (10):1469-1493. doi: 10.1016/S0883-2927(00)00002-0.

López Ferreiro, A. 1899. Historia de la Santa A. M. Iglesia de Santiago de Compostela, Impr. y Enc. del Seminario conciliar central, Santiago de Compostela.

López Pereira, J.E. 1993. Mármoles romanos de la iglesia de Santiago de Alfonso III: determinación de su procedencia, Madrider Mitteilungen, 34: 275-281.

Morabito, Z. 2011. Pórtico de la Gloria. Estudio del material pétreo (Caracterización petrográfica-mineralógica y determinación del deterioro). Informe para COOBEC, dentro de la $2^{\mathrm{a}}$ fase de Restauración del Pórtico de la Gloria. 62 pp.

Moralejo Álvarez, S. 1985. Le Porche de la Gloire de la Cathédrale de Compostelle: problèmes de sources et d'interprétation, Les Cahiers de Saint-Michel de Cuxa, 16:92116.

Moralejo Álvarez, S. 1991. Prólogo. In: M. Mateo Sevilla. El Pórtico de la Gloria en la Inglaterra Victoriana. La invención de una obra maestra, Museo Nacional de las Peregrinaciones, Santiago de Compostela. 
Nicolai, B. and Rheidt, K. ed. 2015. Santiago de Compostela: Pilgerarchitektur und bildliche Repräsentation in neuer Perspektive, Peter Lang, Bern.

Nogales, T., Lapuente, P., and Rodà, I. 2017. Dos nuevos retratos de Caesar Augusta (Zaragoza). In: Actes XIV Colloque International sur l'Art Provincial Romain. June 2015, Dijon, France. Iconographie du quotidien dans l'art provincial romain: Modèles régionaux, $44^{\mathrm{e}}$ suppl. à la Revue Archéologique de l'Est, 261-270.

Origlia, F., Gliozzo, E., Meccheri, M., Spangenberg, J.E., Memmi, I.T., and Papi, E. 2011. Mineralogical, petrographic and geochemical characterisation of white and coloured Iberian marbles in the context of the provenancing of some artefacts from Thamusida (Kenitra, Morocco). European Journal of Mineralogy, 23:857-869. doi:10.1127/09351221/2011/0023-2145.

Portela Silva, E., Pallares Méndez, M.C., Gelabert González, J.E., Jiménez Gómez, S., López Alsina, F., and Puentemínguez, J. A. 1985. Le bâtiment à Saint-Jacques de Compostelle (1075-1575): demande, financement, travail et techniques, Cahiers de la Méditerranée. 31:7-34. doi:10.3406/camed.1985.977.

Raitt, L.M. 2014. The Western Façade of Santiago de Compostela: Christian Dominion and Ecclesiastical Rivalry from the Medieval to the Baroque Period. Summer Research Paper 225.

Royo Plumed, H., Lapuente, P., Cuchí, J.A., Brilli, M., and Savin, M-C. 2018. Updated characterization of white Saint-Béat marble. Discrimination parameters from Classical Marbles. In: ASMOSIA XI Interdisciplinary Studies on Ancient Stone. Proceedings of the XI ASMOSIA Conference (Split 2015), ed. D. Matetić Poljak, and K. Marasović, 371-381. Arts Academy in Split and Faculty of Civil Engineering, Architecture and Geodesy, University of Split.

Royo Plumed, H., Lapuente, P., Ros, E., Preite-Martinez, M, and Cuchi, J.A. 2015. Discriminating criteria of Pyrenean Arties marble (Aran Valley, Catalonia) from SaintBéat marbles: evidence of Roman use. In: Interdisciplinary Studies on Ancient Stone. ASMOSIA X. Proceedings of the Tenth International Conference, Rome 21-26 May 2012, ed. P. Pensabene, E. Gasparini, 671-682, "L"erma” di Bretschneider, Rome, Italy. 
Sánchez-Albornoz, C. 1979. Mármoles romanos en la iglesia Alfonsí de Compostela, Revista de la Universidad Complutense, 118:381-384.

Silva, B., Rivas, T., Prieto, B., Casal, M., and Guitián, F. 1994. Forms and factors of weathering in the Cathedral of Santiago de Compostela. In Proceedings of VII International Congress on Deterioration and Conservation of Monuments in the Mediterranean Basin, 743-748, Venice.

Suárez Otero, J. 2003. Del Locus Sancti Iacobi al Burgo de Compostela. In Historia de la Ciudad de Santiago de Compostela, ed. E. Portela Silva, Servicio de Publicaciones de la Universidade de Santiago de Compostela, 49-77.

Vidal Álvarez, S., Gutiérrez Garcia-M., A., and Garcia-Entero, V. 2016. Use of Estremoz marble sculpture in Hispanic Late Antiquity: the sarcophagi. DigitAR - Revista Digital de Arqueología, Arquitectura e Artes, 3:119-128. doi:10.14195/2182-844X_3_14.

Vidal Rodríguez, M. 1926. El Pórtico de la Gloria de la Catedral de Santiago, El Eco Francescano, Santiago de Compostela.

Villa-Amil y Castro, J. 1866. Descripción histórico-artístico-arqueológica de la Catedral de Santiago, Carlos Bailly-Baillière. Madrid.

Ward, M.L. 1978. Studies on the Pórtico de la Gloria at the Cathedral of Santiago de Compostela, PhD dissertation, New York University.

Watson, C. 2000. A Reassessment of the Western Parts of the Romanesque Cathedral of Santiago de Compostela, Journal of the Society of Architectural Historians, 59:502-521. doi:10.2307/991623.

Yzquierdo Perrín, R. 2010. El maestro Mateo y el Pórtico de la Gloria en la Catedral de Santiago, Edilesa, León. 


\section{Figure captions}

Fig.1. Map showing the geographical locations of Santiago de Compostela (Galicia, Spain), the marble districts mentioned in this study and Coria (Cáceres) mentioned in the documentary sources.

Fig. 2. The Portal of Glory artwork with location of the studied pieces (Modified from Cortázar García de Salazar and Sánchez Ledesma, 2017, Santiago Cathedral Project). The three marble columns from the central arcade are SAN1 (northern twisted), SAN2 (mullion) and SAN3 (southern twisted). The marble apostol's head corresponds to SAN4. SAN5 is the homogeneous grey column, located in the small northern arcade.

Fig. 3. The four marble columns studied.

Fig. 4A. Updated isotopic field of O Incio marble district in Galicia, Spain (modified from Gutiérrez Garcia-M. et al. 2016) plotted in the reference isotopic diagram from the fine grained classical marbles (after Gorgoni et al. 2002, with additions from Lapuente et al. 2014 and Attanasio et al. 2015).

Fig. 4B. Isotopic signature of the four white and white/grey marble pieces of the Portal of Glory in an isotopic diagram after Gorgoni et al., 2002, with the Iberian isotopic fields of Macael (Lapuente, Turi and Blanc, 2000), Alconera, Estremoz Anticline and Almadén de la Plata (Lapuente et al. 2014) and the updated isotopic field of O Incio.

Fig. 5. Apostol's head (sample SAN4). On the left: general overview of the piece after restoration with traces of polychromy in a fine-grained white marble with a few thin grey veins. On the right: Microphotograph under crossed polars of the studied sample, image of the faint CL response. In the bottom right corner, a SEM/EDS image showing small dispersed dolomite grains and other accessories.

Fig. 6. Isotopic diagram for grey marbles with data of sample SAN5 (grey Northern column). Classical bigio antico (after Attanasio et al. 2017) and Hispanic marbles (after Lapuente et al. 2014, 2018; and the updated O Incio marble modified here from Gutiérrez Garcia-M. et al. 2016).

\section{Table}

Table 1. Minero-petrographic, CL and isotopic features of the marble pieces sampled. 
Figure 1. Map showing the geographical locations of Santiago de Compostela (Galicia, Spain), the marble districts mentioned in this study and Coria (Cáceres) mentioned in the documentary sources.

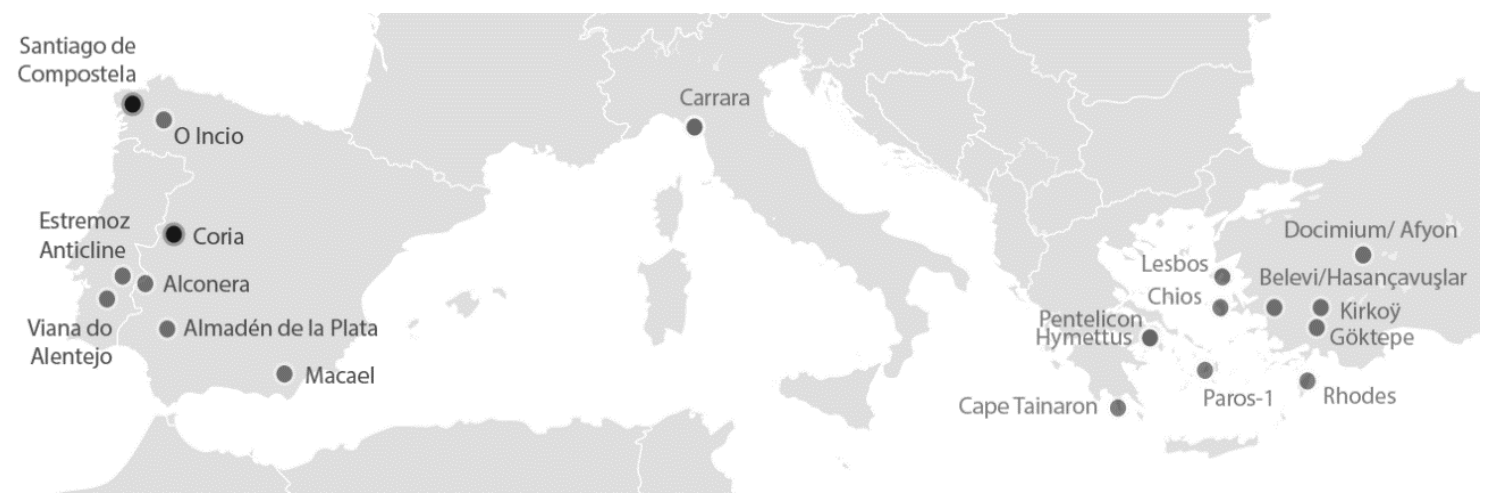


Figure 2. The Portal of Glory artwork with location of the studied pieces (Modified from Cortázar García de Salazar and Sánchez Ledesma, 2017, Santiago Cathedral Project). The three marble columns from the central arcade are SAN1 (northern twisted), SAN2 (mullion) and SAN3 (southern twisted). The marble apostol's head corresponds to SAN4. SAN5 is the homogeneous grey column, located in the small northern arcade.

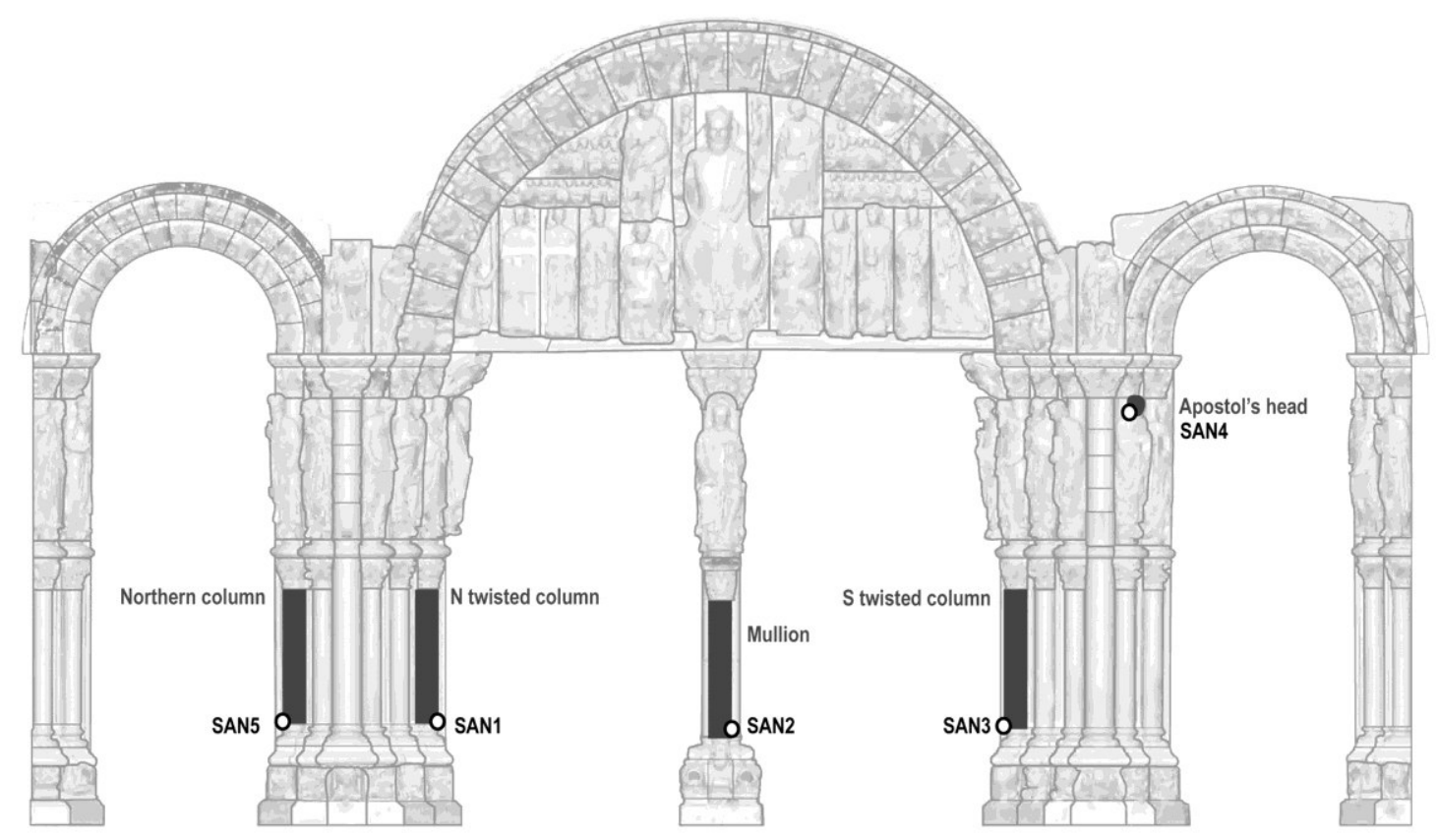


Figure 3. The four marble columns studied.

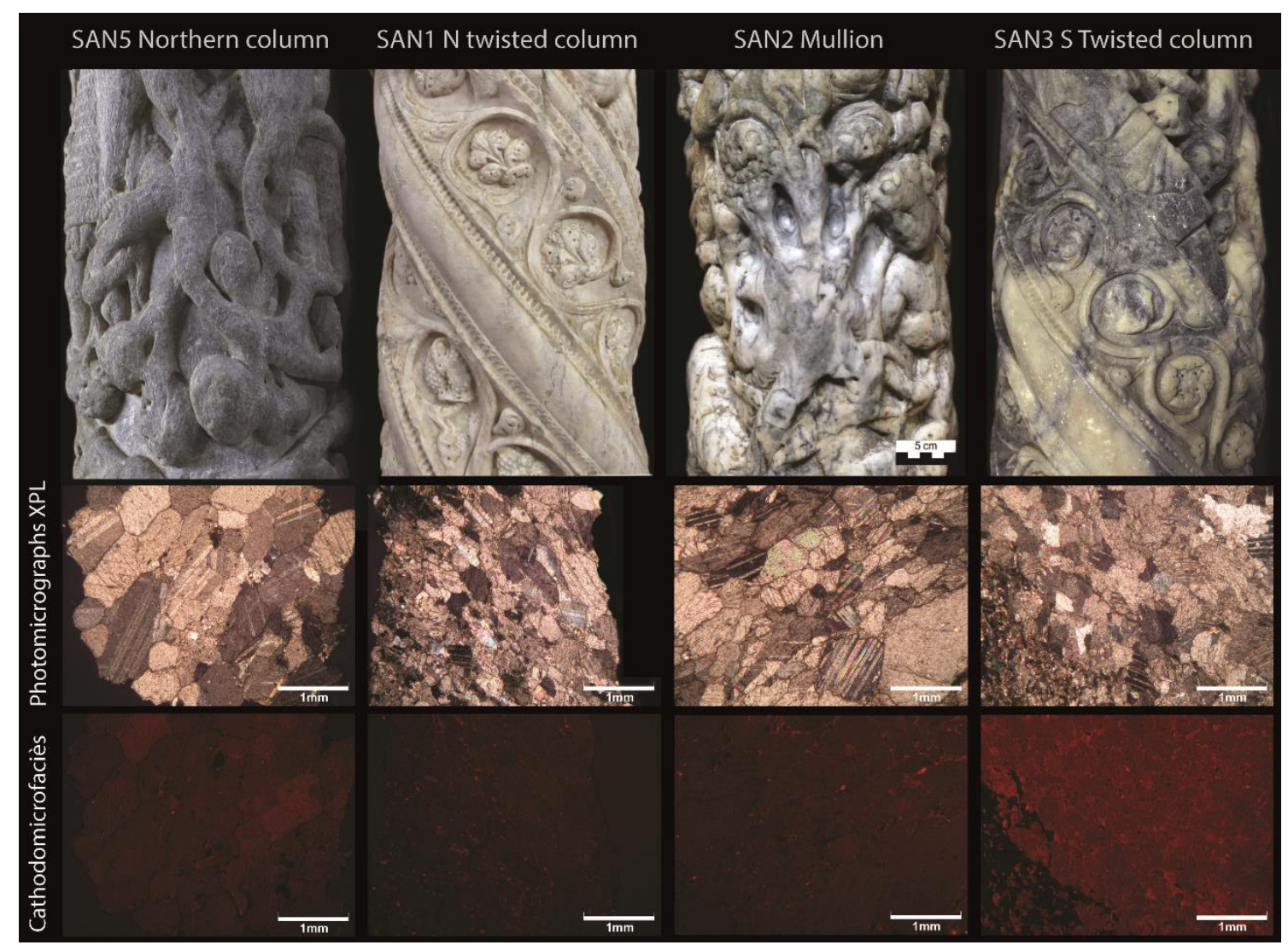


Figure 4A. Updated isotopic field of O Incio marble district in Galicia, Spain (modified from Gutiérrez Garcia-M. et al. 2016) plotted in the reference isotopic diagram from the fine grained classical marbles (after Gorgoni et al. 2002, with additions from Lapuente et al. 2014 and Attanasio et al. 2015).

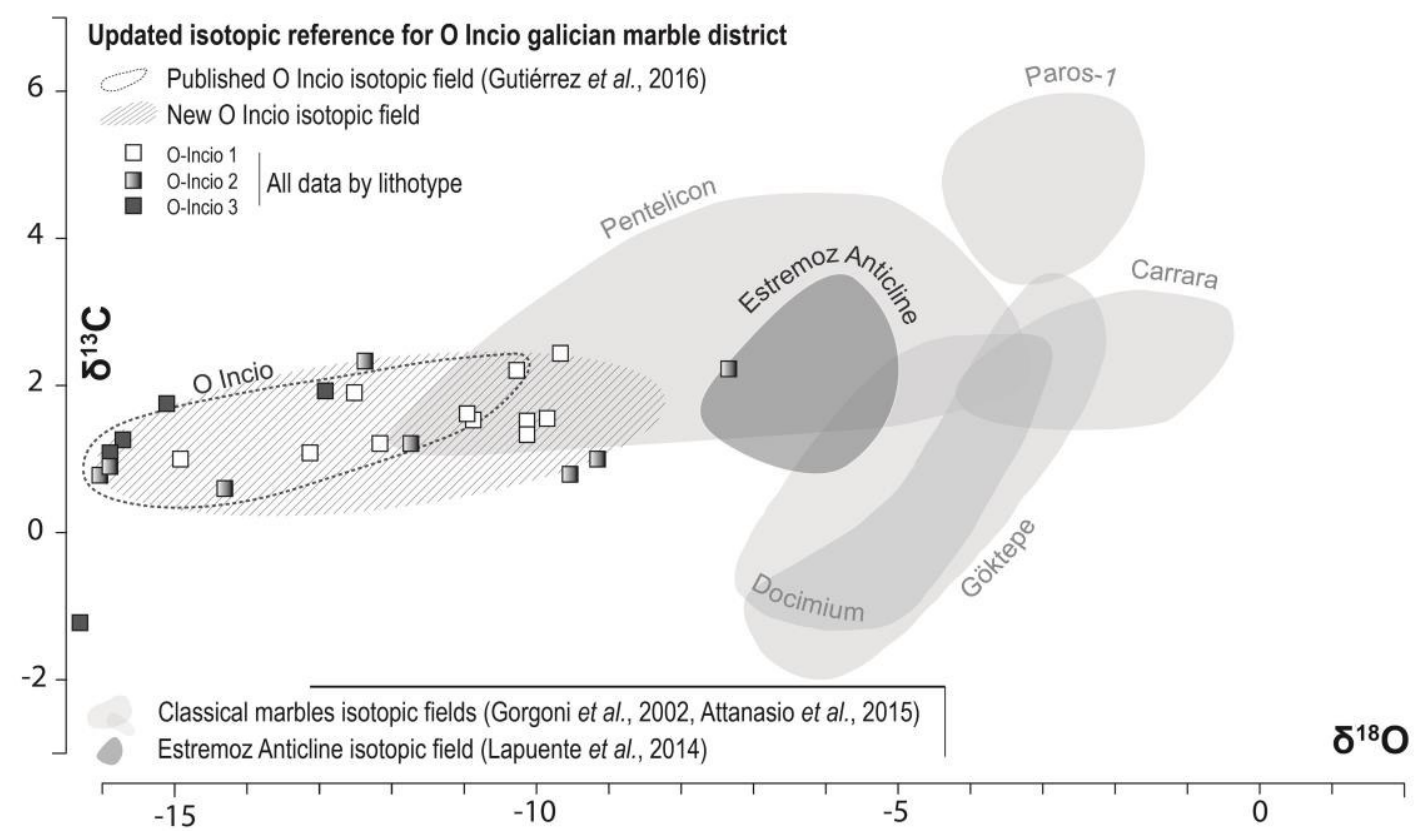

Figure 4B. Isotopic signature of the four white and white/grey marble pieces of the Portal of Glory in an isotopic diagram after Gorgoni et al., 2002, with the Iberian isotopic fields of Macael (Lapuente, Turi and Blanc, 2000), Alconera, Estremoz Anticline and Almadén de la Plata (Lapuente et al. 2014) and the updated isotopic field of O Incio.

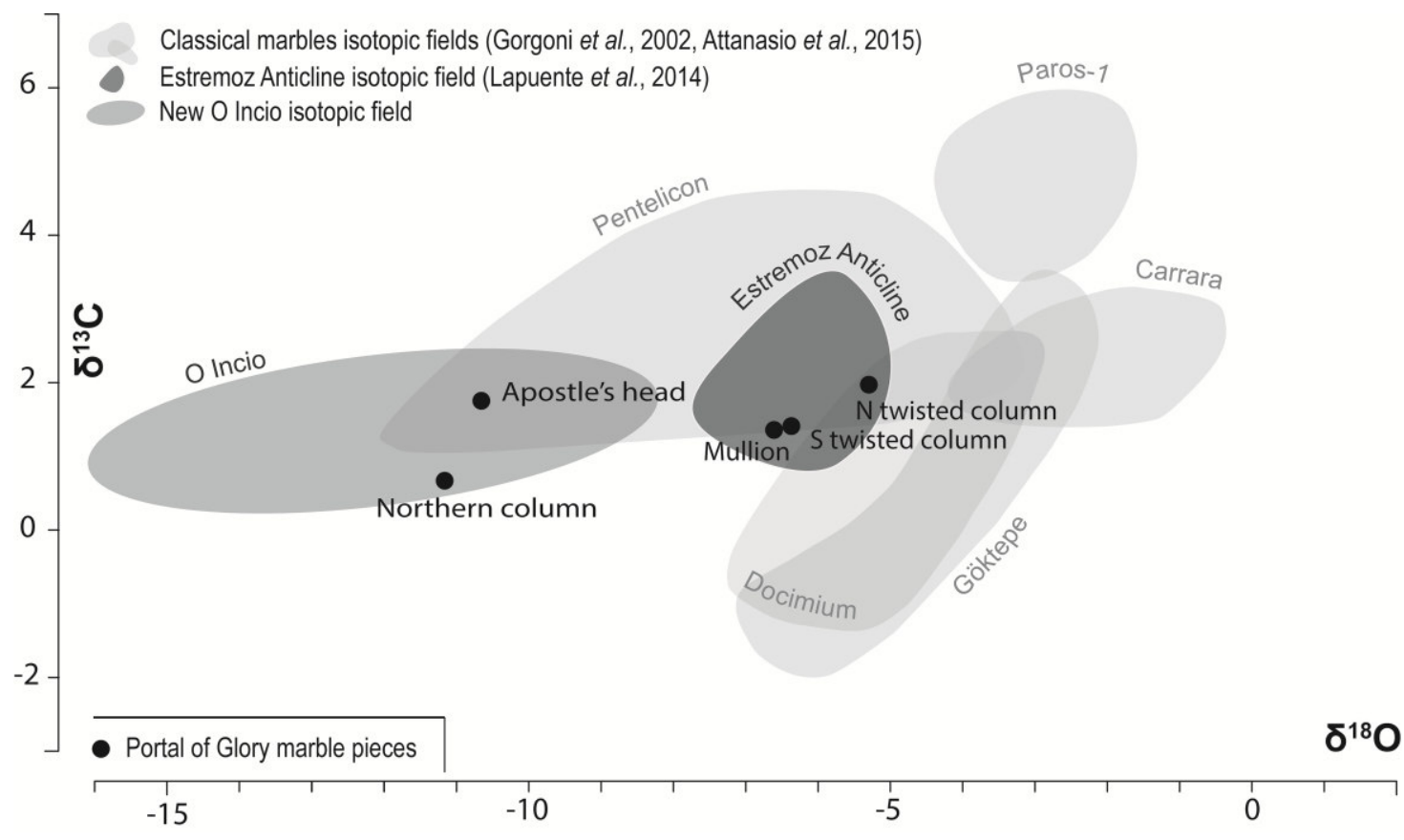


Figure 5. Apostle's head (sample SAN4). On the left: general overview of the piece after restoration with traces of polychromy in a fine-grained white marble with a few thin gray veins. On the right: Microphotograph under crossed polars of the studied sample, image of the faint CL response. In the bottom right corner, a SEM/EDS image showing small dispersed dolomite grains and other accessories.

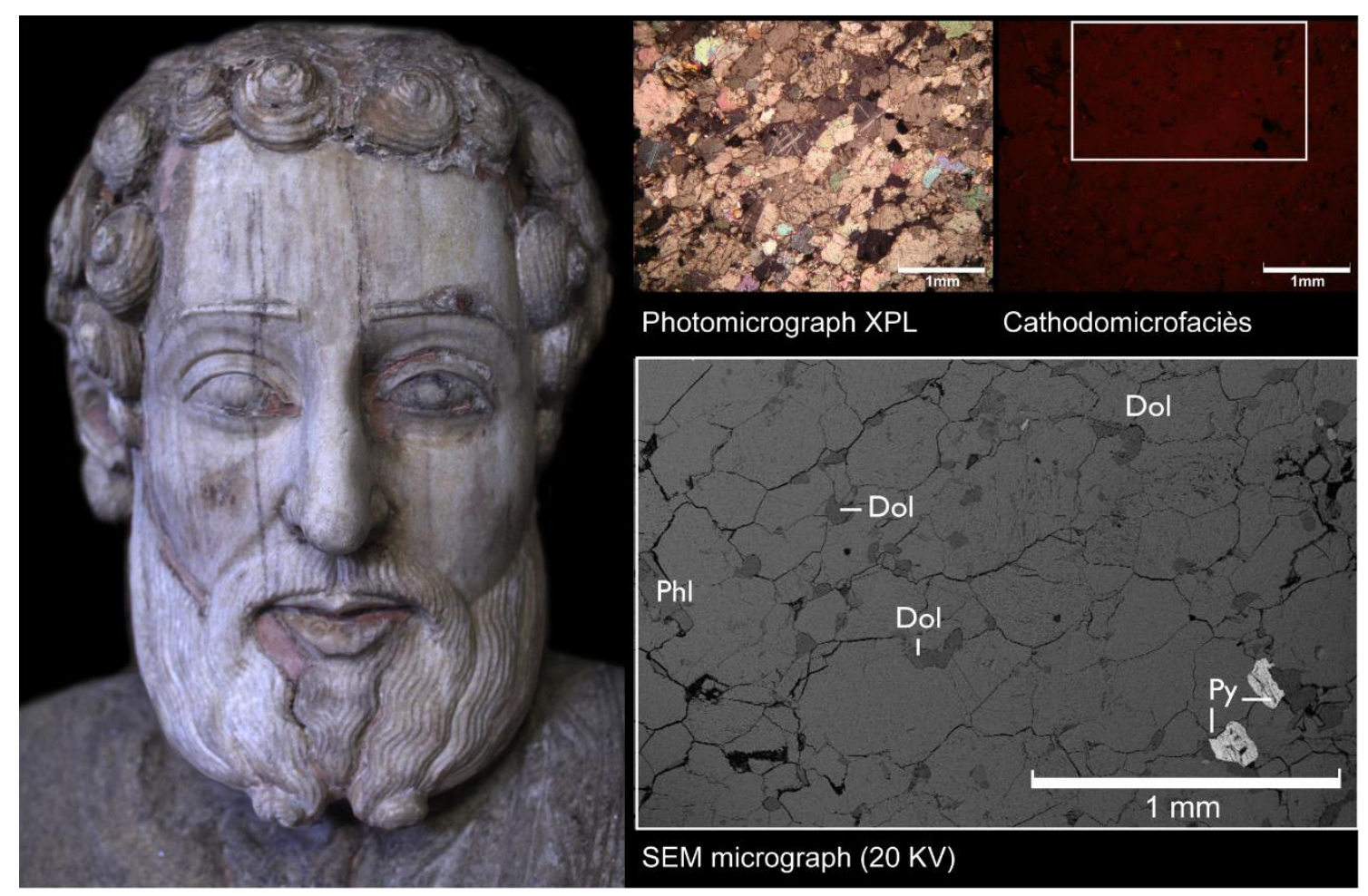


Figure 6. Isotopic diagram for grey marbles with data of sample SAN5 (grey Northern column). Classical bigio antico (after Attanasio et al. 2017) and Hispanic marbles (after Lapuente et al. 2014, 2018; and the updated O Incio marble modified here from Gutiérrez Garcia-M. et al. 2016).

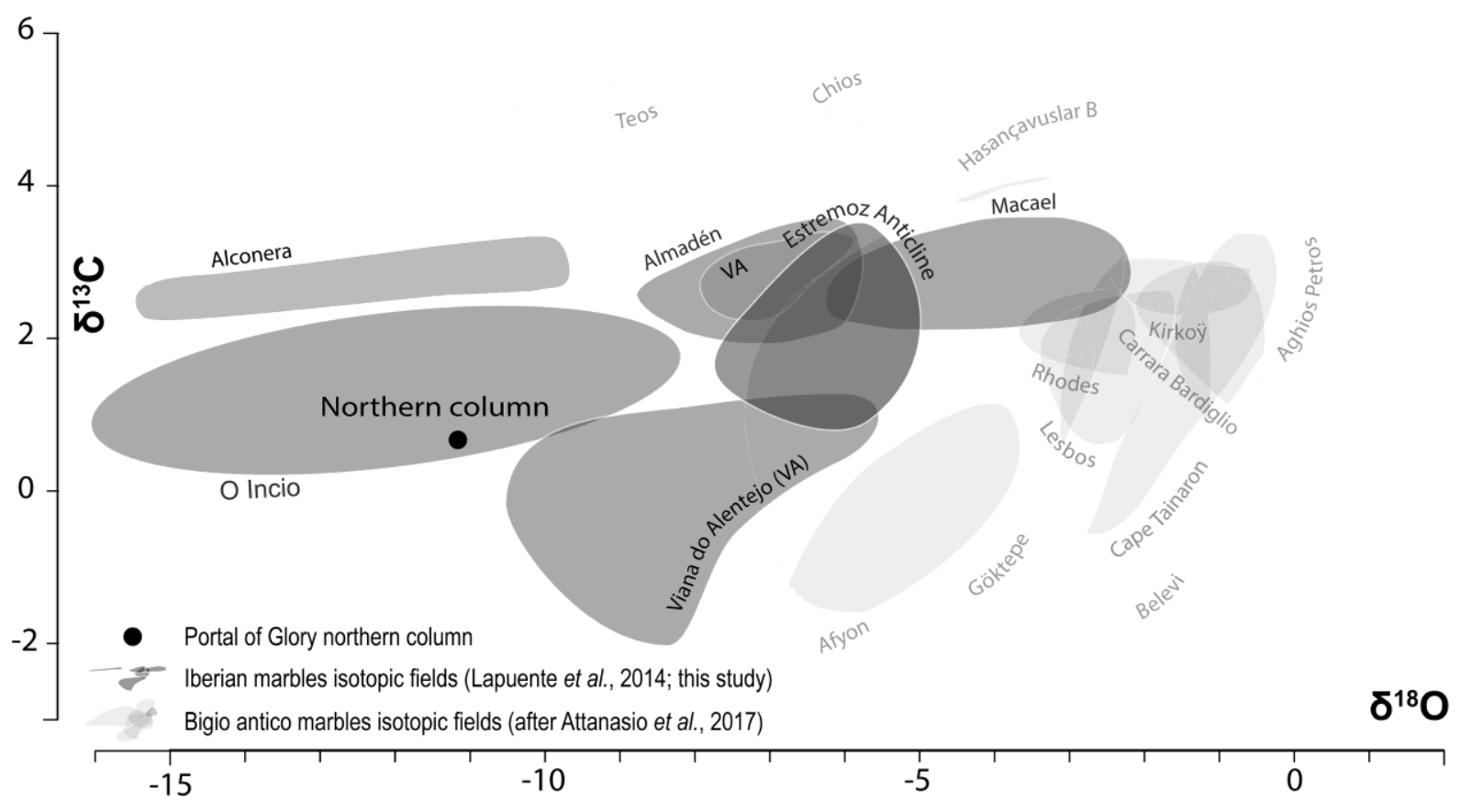




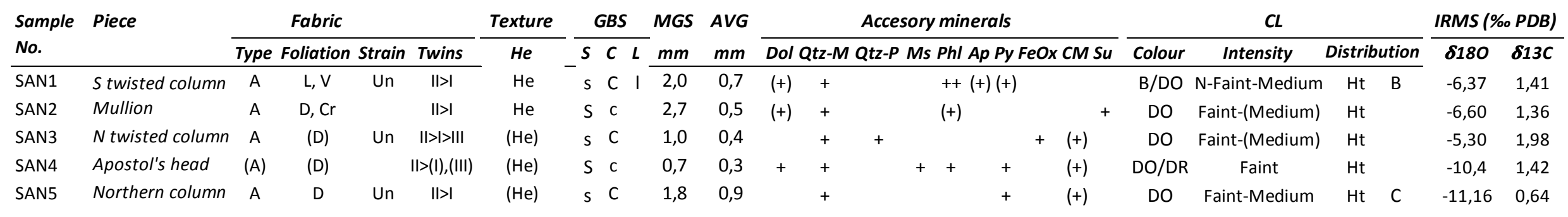

FABRIC TYPE: A, Anisotropic. (), sligthly.

FOLIATION: D, Deformed shape grain; L, Lenticular or banded aggregates; $V$, Size grain variation; Cr, Crystallographic preferred orientation. (), rare.

STRAIN: Un, Undulatory extinction.

TWINS: Twins type I,II,III, after Burkhard (1993). (), rare.

TEXTURE: He, Heteroblastic; (), sligthly

GBS: Grain boundary shape. S, Straight; C, Curved; L, Lobulated; E, Embayed; small letter: minority; capital letter: majority.

ACCESSORIES: (), microcristalline crystals, +, rare; ++, trace; +++, abundant; Do, dolomite; Qtz-M, monocrystalline quartz, Qtz-P, polycristalline quartz, Ms, muscovite; Phl, phlogopite; Ap, apatite; Py, pyrite; FeOx, iron oxyde; CM, carboneous matter; Su, sulphide

CL COLOUR: B, Black; DO, Dark Orange; DR, Dark Red

CLINTENSITY: N, Null; (), millimetric spots

CL DISTRIBUTION: Ht, heterogeneous; C, different intensities related to several specific crystals; B, associated to lenticular or banded aggregates.

Table 1. Minero-petrographic, CL and isotopic features of the marble pieces sampled. 
